\title{
Zangbeto, a Form of Emotional Intelligence
}

\author{
EDOH Koffi Pierrot
}

\begin{abstract}
Zangbeto or traditional night guardian, is a very well-known spirit or a deity in the southern communities of the Republic of Benin, in several other communities of West Africa and particularly in the city of Badagry in south western Nigeria. According to legend, Zangbeto was invented by princes from Adja Tado (Republic of Togo) during their migrations eastward. This with the aim of overcoming their adventure-related uncertainties. To materialize that project, they were disguised with branches and leaves of raffia and other unusual objects in order to have a strange allure to the point of not being recognized on the one hand and on the other hand, to scare people on their way. This find will be perpetuated by their descendants who will use it to ensure the security of their territory once settled permanently. They will also use it during some risky night journeys to spread fear around, then reduce their own concerns and then reassure themselves. The objective of this review is to compare Zangbeto with Emotional Intelligence (EI), which consists of using negative emotions and those of his opponents in some ways to sow doubt in the latter's mind, in order to improve oneself motivations and achieve the goals set.
\end{abstract}

From this work finding, it appears that Zangbeto is actually a form of emotional intelligence that existed before Salovey and Mayer had theorized this concept in 1990. But his status as deity due to his mysterious aspect makes him less accessible and prevents him from being made available to modern knowledge. This allows the Zangbeto to remain sustainable over years and to ensure his role as night guardian in the communities where he exists, despite the evolution of conventional security means.

Index Terms- Emotional Management, Fear, Night-Guardian, Security.

\section{INTRODUCTION}

Zangbeto or traditional night guardian, is a deity from the Republic of Benin in West Africa. Thanks to migratory movements, he has spread to several other communities in the sub-region and elsewhere where black people live. Mainly nocturnal, Zangbeto sometimes comes out during the day to perform spectacular dances and magic demonstrations (traditional Zangbeto festivals) attracting, moving and impressing the audience of adepts and laymen of all kinds. To non-adept individuals who like to attend to his shows, Zangbeto is only known under his day appearance.

Only an initiated person (a Zangan), who assist the deity during his nocturnal outings, can be aware of the form in

EDOH Koffi Pierrot, Unité de Recherche en Psychologie Sociale et Animation (UR-PSA), Institut National de la Jeunesse, de l'Education Physique et du Sport (INJEPS), Université d'Abomey Calavi (UAC), 01 BP 169 INJEPS - Porto-Novo -République du Bénin which he appears during the night. But it must nevertheless be pointed out that it is not possible for a layman to appreciate all the relations that a Zangan can have with this deity during his nocturnal missions, nor to establish the limits. During these outings, the adepts or Zangan organize intermittent animations that can be enjoyed by the lay people who are out of sleep, from the bed of their room and in the silence and darkness of the night. The original functions of this divinity, which are similar to Emotional Intelligence [1], have nowadays been somewhat altered and distorted to the point where Zangbeto tends to become an object of media spectacles. For example, non-traditional events bring together Zangbetos from different horizons in front of reporters' cameras to compete ferociously with their ability to innovate in dances and, especially in magic demonstrations. All of this with the sole purpose of receiving awards from laymen's jury verdicts (non-Zangbeto-initiated individuals). People made of flesh and bone who evaluate divinities, sacred entities, spirits, etc. Under other circumstances, one would have spoken of profanation or sacrilege. This is not the case, however. The "Zangbeto festival", the organizing structure of these events which take place periodically in Cotonou (economic capital of Benin), justifies the organization of these events by its concern to revalue the national cultural heritage. For several decades, these types of exhibitions have multiplied and compelled Zangbeto to leave his land periodically, thus momentarily giving up his primary function. However, once back home, the night watchman returns to his original duty of continuing to assist his community members by protecting them from being robbed and therefore ensuring their peace. The present study is not presented as a classical research work, but as a review because part of its object is based on knowledge referring to sanctity, to religious beliefs. This makes investigations more complex. The information provided by the respondents depends on their status in the community (adept or non-adept) and also on the status of the researcher himself. In view of these difficulties, the following work is devoted especially to the Zangbeto divinity. Unfortunately, scientific documents in this sense to try to make the link between the role of this deity and Emotional Intelligence are not abundant either. But in reality, how was Zangbeto originally? When, how and where did it first appear?

\section{ZANGBETO}

Explanation of Zangbeto origin is based on a legend in which a hunter plays a vital role. Indeed, it was a hunter who, according to the legend, provided one of the important elements of the materialization of Zangbeto to a prince of Adja Tado who conceived what will become the impressive god. This in the perspective of a risky migration with his family. These elements are the horns of large wild animals. 


\section{A. The legend}

It was told by two Zangans who were called for circumstance $\mathrm{Z}$ and $\mathrm{H}$. They reported that at the beginning of the 17th century, after a conflict among the princes of Adja Tado (presently located in the Republic of Togo), a group of three princes had decided to leave the place to move further west. In order to face the various uncertainties associated with such a journey and to ensure the safety of the group during the journey, one of the princes had imagined what would later become the spirit of "Zangbeto". Thus, he will ask the group to disguise themselves with dry leaves of banana trees, branches of coconut palms, as well as leaves of bamboo and raphia; all stuffed with snail shells and other objects that can make unusual sounds in the darkness of the night as they move [2]. Moreover, he will get big game horns that he will turn into horn whistle thanks to the hunter who is also part of the expedition. Then some members of the group were provided with the said horn whistles. And during their nocturnal migrations, these huge whistles were frequently blown. The intermittent sounds of the horns, along with the incessant sounds of shells and dry leaves, caused fear in the migrants' surroundings, who, comforted by this finding, cheerfully pursued their journey. It should be noted that during this migration, which would have lasted several months, the journey was made only at night, and the members of the group rested the days while they hid under the foliage, the materials having served them in disguise at night.

After crossing the Lake Aheme [3], the group will stay for a while at Dedome (commune of "Kpomasse" in the "Atlantique department") before moving to "Allada," a commune of the same department in the Republic of Benin, where they thought they would settle permanently. Very soon, however, another dispute will force the group to separate again. One of them will stay in Allada, where he will found his kingdom (Kingdom of Allada). The second will continue northward and settle in Danhome, where he found his kingdom (presently called kingdom of Abomey). As for the third, he continued his adventure eastward and reached "Hogbonou" where he found the kingdom of Hogbonou (the kingdom whose city is now Porto-Novo, the administrative capital of the Republic of Benin). This latter will be the one between the three princes to perpetuate the Zangbeto. In fact, according to the Zangan $H$, as soon as the latter moves to Hogbonou (Porto Novo), he asked the hunter of the group, the very one who supplied the whistle horns (thanks to which the original group was able to spread fear among those who could hinder them in their progress) to settle not far from his palace in order to continue to ensure his safety and that of their community.

That's how the legend Zangbeto (night-guardian) was born. (zan: night, gbeto: hunter, Zan-Gbeto: night-hunter and later called night-gardian). Zangbeto, better than Emotional Intelligence, is an original way to reassure and motivate oneself by rejecting part of one's fear on all subjects likely to impress and produce negative emotions on us. It was therefore from Porto Novo that the Zangbeto god and spirit spread to the other southern areas of West Africa.

\section{B. Nowadays' Zangbeto}

Zangbeto has evolved at the pace of society and its setting environment. In general, he is now in the form of "mobile conical boxes or Zanho", he can be on feet or not [2]. When conceived and realized on feet, "possessed" or not by the spirit or the divinity, he holds almost the same posture. Otherwise, he stays on the ground when he is at rest and rises when he is inhabited by the spirit of Zangbeto. Thus, the Zangbeto divinity can be categorized into two broad forms on the basis of its costumes. The size are functions of the form, but they can also be variation within the same form (Figure $1 \& 2)$. The decoration or accoutrement, made of raphia and bamboo leaves, is often bright in colour. It is possible to use other materials for its realization. In fact, confessional materials may vary from region to region. The confession of the Zanho (Zangbeto costumes), are the work of people selected from the skilled and advanced adepts (Zangan). No layman can know where and how the costumes of Zangbeto are designed and made. It is only during events dedicated to their outings (traditional Zangbeto festivals) that lay people can discover them. Each Zanho has a name, possibly depending on the spirit living in it. The Zanho are also called by the name Zangbeto followed by their specific name (example Zangbeto Ate, Zangbeto Keke, ...). Zangbeto is at the same time god, spirit, religious belief, tradition and symbol [4]. As such, no lay person should touch a Zangbeto or an object related to that spirit because, like all its accessories, a Zanho can be inhabited by the Zangbeto spirit at any time.



Source: Eisenlager \& Jack Hertz (2017).

Figure 1: Zanho or zangbeto box (not on feet and possessed by the spirit)



Source: Noussouglo(2011).

Figure 2: Zanho or zangbeto box on feet at rest.

Dances, pirouettes and various performance techniques are influenced by the Zanho form (on feet or not). Some types of Zangbeto are especially known for their spectacular dances, which attract countless crowds of fans or curious people. According to [2], Zangbeto Ataho is the best dancer and master of traditional Zangbeto festivals. But beyond dances, 
it is the magical demonstrations of the Zangbeto which make his specificity and fascinate fans in the communities. Because these magic demonstrations are beyond public understanding, they cause stupefaction and affirm in the minds of the very people that Zangbeto is a true divinity, the master of the night, their indefectible protector. This is certainly part of the elements that make the community member fear and respect the divinity. It also reinforces his position as a mystical night guardian and follows the pattern of Emotional Intelligence. After his prowess, he performs a kind of honorary procession with specific cadences where he is particularly adulated. This is one of the most memorable moments when people, especially women, praise him with songs and cries: Azoo, Azoo, Azoo ... [4]. They also chant the specific names of the Zangbeto, sprinkling them with perfumes and cosmetic powders. This is their way of communicating with the deity. But they can't touch a Zanho in any way. After the exhibition, the Zangbetos retire to their convent, where only the adepts have access to.

The forms of presentation of the deity at night remain in the discretion of the adepts who are bound by the professional secrecy. His night outs are generally announced by three sets of gongs spaced for a few minutes (about 10-15 minutes). This leaves time for people to make arrangements to safely return home or pack their luggage. At the third series of gongs, everyone has to be in his room where the lights have to be off. No layman has ever seen the author of the gongs announcing the Zangbeto outing. What gives rise to speculation. People wonder if the outing announcement is perform by the very divinity. Operating only in the darkness of the night, he only comes out exceptionally during periods of moonlight.

Some outings may be unannounced and be at the discretion of the Zangbeto spirit. They can intervene late at night, when most of the community members are supposed to be at home, or early at night, and they can surprise lay people who will be forced to ask for a safe way (to their adept counterparts) to go home. This is also the same for everyone who has to go in the community while Zangbeto watches. In this case, he must make himself known from afar, by stating his names, his origin, and the reasons for his absence from the community. If he's a stranger, he has to reveal the identity of the person he's going to meet, and what are the reasons of the meeting. Generally, he (Zangbeto) asks one of the initiates who assist him to accompany and guide the concerned people. However, it is not excluded that he refuses to allow a foreigner access to the community or even to arrest him if the information provided is not convincing. Only good-matured adult men can be initiated (become Zangan). They are the ones who have access to the convent during the ceremonies and who can attend the divinity days and nights. Thieves and people of doubted morals are forbidden to be initiate to this deity.

\section{EMOTIONAL INTELLIGENCE}

Proposed in 1990 by psychologists Peter Salovey and John Mayer [5], Emotional Intelligence (EI) refers to the ability of individuals to recognize and manage their own emotions and to cope with and control the emotions of others. Close to the concept of social intelligence, it was popularized by Daniel Goleman in 1995 and modified and completed two years later in 1997. Since EI is defined as: "The ability to perceive and explain emotions, to integrate them in order to facilitate thinking, to understand and reason with emotions, and to regulate emotions at home and among others" [1]. In other-words, it is the ability to use negative emotions (fear, stress, anxiety) and those of others (real or virtual opponents) to solve problems. For [6], it is the intelligent use of emotions in order to achieve a desired goal.

It can therefore intervene in a number of social sectors of life (leadership, human resources management, business, ... [7], [8] and in sport to control aggressive tendencies [9], [10]. In the sport disciplines, athletes use EI to impress their opponents, generate doubt, confusion and fear on them, and at the same time galvanize themselves [11]. If Emotional Intelligence is used in sport in general, it is more so in sports of direct opposition such as boxing, judo, where athletes begin to challenge each other even before the day of the fight (for example, during boxer weighing). For example, on the occasion of the fight between George Forman and Mohamed Ali in 1974 in Kinshasa, to evacuate his fear and put more pressure on Forman, Mohamed Ali as soon as he got off the plane had undertaken to spread in the crowd in Congolese national language that his challenger is a Belgian. This had been repeated by his fans who had chanted it throughout the city: "Forman is Belgian, Forman is Belgian, ...". It should be noted that Congo (Democratic Republic of Congo or Zaire according to the periods) is a former Belgian colony and Congolese are still mad at the Belgians at the time.

Object of stress management and motivation in various fields, Zangbeto has been invented since the 17th century in traditional communities to cover night trips and ensure the quietness in villages. But what kind of relationship can be established between the Emotional Intelligence, which is scientific knowledge, and Zangbeto, which is a traditional knowledge and a divinity. Is it possible to consider Zangbeto as a form of Emotional Intelligence?

\section{ZANGBETO AS STRESS AND MOTIVATION PREVENTION STRATEGIES}

Zangbeto as traditional knowledge predates the theorization of the concept of Emotional Intelligence in 1990. As scientific knowledge, Emotional Intelligence relies on theories that allow to verify a number of facts and to help improve [6], [12]. On the contrary, Zangbeto, a form of traditional belief, thus a knowledge of common sense erected to the rank of religious belief, spirit, ..., alas, requires an initiation to be admitted to the rank of his adepts (member of his group) and to actually understand all his aspects. As a result of knowledge of common sense, it is unfortunately more naive than true [13]. The assessment of the information concerning him depends on the status of the persons between whom they circulate. The consequence is that according to whether they are initiated persons, information relating to the Zangbeto deity is diffused in a certain way. If the same information has to be announced by a non-initiated to members of his group, the version changes. The information in this context differs depending on whether it circulates between adepts, between the non-adepts or between adepts and non-adepts. If exchanges must be made between adepts in the presence of non-adepts, the former make use of coded language or sometimes ask the latter to withdraw from the premises, even if it is a public place. Those that circulate between adepts can never be between adepts and laymen. The latter should be content with what they want them to know 
and understand officially. According to [4], the Zangbeto spirit appears and takes possession of the Zangan as the Holy Spirit appeared at Pentecost, taking possession of the apostles who had begun to preach in different languages, forgetting their fear since the crucifixion of Jesus-Christ 50 days earlier.

In such a context, where Zangbeto enjoys the status of a subtle majority in the communities where it is implanted, compliance remains the golden rule, and non-adepts willingly accept all information, even the very fabulous information related to divinity. All members of the community (non-adepts and women), have faith and willingly accept what they are told. It is not necessarily true information, but what goes in line with the Zangbeto's magnificence, what the group of initiates (Zangan) spread as truth, and it is imperative to accept to convey that to be in harmony with the majority of community members [14].

Finally, no one really knows what Zangbeto is, or that everyone (the non-adept and the women included) knows it, but they all stick to the official version; that of the subtle majority. Because those who are supposed to know it (the Zangan: the highest ranking of adepts) are not allowed to speak publicly about it, because information belonging to a group remains the property of the group and not that of other members to dispose of it as they please. Under these conditions, each member according to the subgroup to which he belongs in the community has his understanding which is probably different from the official one. But everyone admits that he is inaccessible because he is capable of all feats, of multiplying, of becoming an animal or a statuette, of speaking a language that is not that of the community [4]. Despite ages and modernity, this keeps the Zangbeto myth intact.

Beyond the official version, since information or knowledge about Zangbeto is actually different depending on whether or not one is initiated, it creates a kind of mystery around this divinity and its practices. The information circulating about him predicts that his magical powers is unlimited. "He can see and hear everything from a distance; he can see everything in the dark; he can hear everything that has been said about him, and he can anticipate everything". Zangbetos are definitely feared by everyone, including the Zangans themselves, at least officially [4]. As soon as the very powerful voice of Zangbeto resounds in the dark night, all those outside, on his territory, are frightened. Then follows a rout, because no one is safe from reprisals. That where his power lies, to maintain and spread fear. Since there are no differences between the spirit and the Zangan who assist Zangbeto at night, at that very moment of darkness the Zangan can multiply and find himself in several places at the same time or in a very short period of time [4]. If by chance, a suspect is somewhere in this environment and hears the thundering spirit almost at the same time saying in different places: "I see you, you want to tempt me, no one plays with me with impunity", the suspect is forced to sneak away at the best of times or give up and surrender to limit the anger and retaliation of the dreaded night guard.

We are entitled to wonder how Zangbeto operates at night. Why is he often threatening? Is this not to scare potential suspects and reassure himself that he spreads fear? The reality is that this is his original operating mode; the one by which he fulfils his responsibilities: Provoke fear and control others' emotions in order to prevent and better manage his own negative emotions.
For Stéphanie Milot, the Emotional Intelligence comes in 4 steps that are:

$\checkmark$ The self-awareness that allows everyone to know their negative emotions (fear, stress, anxiety, ...): Zangbeto knows his emotions, he's afraid of being discovered. The princes who left Adja Tado were afraid of being recognized and attacked, that's why they imagined this stratagem);

$\checkmark \quad$ The self-management, where everyone must be able to take care of themselves daily not to avoid negative emotions, but to manage them at best: Zangbeto manages his negative emotions by spreading fear among other "humans" during his outings at night. The princes of Adja Tado were aware of their negative emotions. To manage them at best, they had imagined this trick;

$\checkmark \quad$ Be aware of the emotions of others in the management of one's emotions: Zangbeto is aware of the emotions of men. He knows they are afraid of him and he exploits that situation to his advantage. The princes who left Tado knew that whoever met them would panic;

$\checkmark \quad$ Management of relationships with others: Zangbeto uses his own emotions and those of men to develop his interactions with them. His strategies are to put pressure on humans as did his initiators who left Adja Tado.

Zangbeto is aware of his emotions. He is afraid of being discovered. That's why he disguises himself and operates in the dark so that we cannot recognize him. He also knows that he is feared by people who are convinced of his powers and who try to live in discipline with the rule of the Deity in order to avoid his anger. In order to accentuate this state of fear among potential suspects, he moves perpetually and splits himself so that he won't be located and thus becomes elusive and scares off fearful enemies.

When he goes out in a community to ensure security at night, no case of robbery is recorded on the territory. His presence dissuades the potential thugs who are deported to other areas that they often record cases of theft. To prevent this situation, since almost all the communities where Zangbeto is known have adopted him, when he goes on watching in a village, people of neighbouring communities often go out and organize themselves to assure security in order to prevent potential thugs from taking advantage of the absence of Zangbeto to rob them.

\section{CONCLUSION}

At the end of this review, we understand that Zangbeto exists in the Beninese communities well before the African independence of the 1960s. Its advent therefore precedes the proposal of the concept of Emotional Intelligence, which dates back only to the 1990s. His security power and reputation have increased to the point where he can even stand as an exceptional court to hear and judge disputes between members of his community. His judgement is without recourse and feared by everyone. But unfortunately or fortunately the Zangbeto cannot become a modern and legal institution because it is stamped with the seal of religious belief. In addition to his increasingly sound opinions, it is his divine character that enables Zangbeto to continue to stand and reign supreme in the communities where he exists. The Zangbeto deity, through his role as the guarantor of security in rural areas, provides evidence that endogenous beliefs and practices need to be preserved and restored where they no longer exist. Some communities that 
do not have one continue to take steps to introduce him in their Locality. Zangbeto, the night guardian or emotional intelligence in traditional circles is an endogenous knowledge that still has, as we can see, beautiful days to live. But in order to live in this way, he needs to focus more on his original role and avoid compromise even if he has to adapt to modernity.

Since the spirit of Zangbeto can descend on the Zangan like the Holy Spirit on the apostles on the day of Pentecost, any Zangan could be possessed by the spirit of Zangbeto in order to avoid inconvenience at times of hardship. By doing so, the Zangbeto spirit or deity will be able to play his role fully in accordance with the expectations of his initiators centuries ago. There are, therefore, risks of excesses that those responsible (Zangan) should intrinsically avoid. That why the first requirement to be initiated to the divinity is to be a man of morality and integrity.

Finally, women are prohibited from being initiated to the Zangbeto divinity and cannot aspire to the function of Zangan even though the group that left Adja Tado century ago was composed of women. Their only role is to praise the god with song and dance at traditional festivals. What brings to the question, why can't women be initiated and become adepts of the Zangbeto divinity?

\section{REFERENCES}

[1] Mayer J, Salovey P (1997). "What is emotional intelligence?', in Salovey P and Sluyter D (Eds), Emotional Development and Emotional Intelligence: Implications for Educators, Basic Books, New York, NY, pp. 3-31.

[2] Okure D (2016). Symbolism and Social Control of Zangbeto among the Ogu of southwestern Nigeria. CAES, Volume 2, n², pp. 10-30. H. Poor, An Introduction to Signal Detection and Estimation. New York: Springer-Verlag, 1985, ch. 4.

[3] Edoh K P, Messan F, Dossou-Sognon A (2014). Problématique d'une gestion intercommunale du lac Ahémé et ses chenaux. J. Rech. Sci. Univ. Lomé (Togo), Série B, 16 (2), 427-437.

[4] Dukor M (2014). Philosophical Signifiance of Myths and symbols: Zangbéto cults. International Journal of Humanities Social Sciences and Education (IJHSSE), volume 1, Issue 11, pp.23-34.

[5] Dosseville, F, Edoh K P (2015). Les compétences émotionnelles en équitation. Le magazine en ligne de l'actualité technique et scientifique équine, équ'idée, pp. 1-3.

[6] Goleman D (1997). Emotional Intelligence. Batam Books, New York.

[7] Bobot L (2010). L'Intelligence Emotionnelle est-elle un atout en négociation commerciale ? Management et avenir, $\mathrm{n}^{\circ} 31$, pp. 407-430.

[8] Baqué C, Pierre J (2012). Amélioration de la performance en entreprise par la pratique d'activités sportives. In Psychologie du Sport et de la Performance, sous la direction de Greg Décamps, pp. 323-337.

[9] Dosseville F, Garncarzyk C (2007). L'arbitrage des pratiques sportives : Jugement et décision, in Bulletin de psychologie, $\mathrm{n}^{\circ} 489$, pp. 225-237.

[10] Dosseville F, Laborde S, Edoh K P, Garcarzyk C (2016). Le rôle de l'intelligence émotionnelle dans les comportements agressifs dans le domaine sportif. Revue STAPS. Doi : 10.3917/sta.112.0033.

[11] Emotional intelligence in sport and exercise: A systematic review, Scandinavian Journal of Medicine and Science in Sports 26(8), 862-874. DOI: $10.1111 / \mathrm{sms} .12510$

[12] Goleman D (1995). L'Intelligence Emotionnelle : Comment transformer ses émotions en intelligence. Bitam Books, New York.

[13] Moscovici S, Hewstone M (1983). Social representations and social explanations: from the «naive » to the «amateur » scientist, in $\mathrm{M}$. Hewstone (ed), Attribution theory: Social and functional extentions, Oxford, Basil Blackwel.

[14] Edoh K P, Boukary A B (2019). Students'Beliefs about their Interactions with Lecturers: Case of the National Institute of Youth, Physical Education and Sport (INJEPS), Psychology, 10, 682-693. DOI: $10.4236 /$ psych.2019.105043 